\title{
PENERAPAN MODEL PEMBELAJARAN TEAM ASSISTED INDIVIDUALIZATION (TAI) DENGAN BERBANTUAN LEMBAR KERJA SISWA (LKS) UNTUK MENINGKATKAN MOTIVASI DAN PRESTASI BELAJAR SISWA PADA MATERI TERMOKIMIA KELAS XI IPA SMA NEGERI 1 SLOGOHIMO TAHUN AJARAN 2015/2016
}

\author{
Niti Asih Saraswati, Agung Nugroho Catur Saputro*, dan Sri Mulyani \\ Program Studi Pendidikan Kimia, FKIP,Universitas Sebelas Maret, Surakarta, Indonesia \\ *keperluan korespondensi, hp: 081329023054, email: anc_saputro@yahoo.co.id
}

\begin{abstract}
ABSTRAK
Penelitian ini bertujuan untuk meningkatkan motivasi dan prestasi belajar siswa pada materi Termokimia kelas XI IPA I SMA Negeri 1 Slogohimo melalui penerapan model pembelajaran Team Assisted Individualization (TAI) berbantuan Lembar Kerja Siswa (LKS). Penelitian ini merupakan penelitian tindakan kelas yang terdiri dari dua siklus. Setiap siklusnya terdiri dari perencanaan tindakan, pelaksanaan tindakan, observasi, dan refleksi. Subjek penelitian adalah siswa XI IPA I SMA Negeri 1 Slogohimo tahun pelajaran 2015/2016. Sumber data adalah guru dan siswa. Data diperoleh melalui wawancara, observasi, tes, dan angket. Teknik analisis data yang digunakan adalah analisis deskriptif kualitatif. Hasil penelitian menunjukkan bahwa penerapan model pembelajaran Team Assisted Individualization (TAI) berbantuan Lembar Kerja Siswa (LKS) dapat meningkatkan motivasi dan prestasi belajar siswa pada materi Termokimia. Peningkatan motivasi belajar siswa dapat dilihat dari kenaikan persentase ketuntasan pada siklus I sebesar $69,23 \%$ meningkat menjadi $100 \%$ pada siklus II. Peningkatan prestasi belajar dapat dilihat dari dua aspek yaitu kognitif dan afektif. Prestasi belajar kognitif pada siklus I ditandai dengan ketuntasan sebesar $46,15 \%$ meningkat menjadi $100 \%$ pada siklus II. Sedangkan pada aspek afektif, ketercapaian pada siklus I sebesar $42,31 \%$ meningkat menjadi $100 \%$ pada siklus II.
\end{abstract}

Kata kunci: penelitian tindakan kelas, team assisted individualization, lembar kerja siswa, motivasi belajar, prestasi belajar

\section{PENDAHULUAN}

Peningkatan kualitas sumber daya manusia merupakan prasyarat untuk mencapai tujuan pembangunan. Salah satu wahana untuk meningkatkan kualitas sumber daya manusia adalah pendidikan. Pendidikan merupakan pengubahan sikap dan perilaku seseorang atau kelompok orang dalam hal mendewasakan manusia melalui upaya pengajaran dan pelatihan. Pendidikan merupakan suatu kebutuhan yang harus dipenuhi dalam proses kehidupan. Majunya suatu bangsa dipengaruhi oleh mutu pendidikan dari bangsa itu sendiri karena pendidikan yang tinggi dapat mencetak sumber daya manusia yang berkualitas.

Salah satu upaya untuk meningkatkan kualitas pendidikan di Indonesia adalah dengan perbaikan sistem pendidikan. Kurikulum yang saat ini diterapkan di Indonesia adalah Kurikulum Tahun 2006 (KTSP) dan Kurikulum 2013. KTSP menuntut adanya keaktifan siswa pada saat proses pembelajaran berlangsung, sehingga peran guru dalam kelas hanya sebagai motivator, dinamisator dan fasilitator untuk membantu siswa dalam belajar [1].

SMA Negeri 1 Slogohimo merupakan salah satu sekolah yang menerapkan kurikulum 2006 (KTSP). 
Namun, dalam penerapannya proses pembelajaran yang berlangsung di SMA Negeri 1 Slogohimo tersebut masih terpusat pada guru (Teacher Centered Learning). Dan kondisi yang teramati adalah prestasi belajar kimia khususnya pada materi termokimia masih relatif rendah.

Berdasarkan wawancara dengan guru kimia kelas XI SMA Negeri 1 Slogohimo pada tanggal 4 Juni 2015 diidentifikasi bahwa materi kimia seperti termokimia dan kelarutan dan hasil kelarutan merupakan materi yang cukup sulit bagi siswa, siswa pada umumnya kesulitan untuk memahami konsep yang terlalu banyak hitungan seperti penentuan entalpi molar standar, dan penentuan entalpi reaksi. $\mathrm{Hal}$ ini kemungkinan motivasi siswa dalam mempelajari kimia terutama pada materi termokimia sangat rendah. Rendahnya motivasi belajar ini membuat banyak siswa yang pasif dan berdampak pada prestasi hasil belajarnya. Hal ini juga didukung dari hasil ulangan harian pada materi termokimia pada kelas XI IPA tahun pelajaran 2014/2015 yang tersaji dalam Tabel 1.

Tabel 1. Nilai Ulangan Harian Materi Termokimia

\begin{tabular}{lcc}
\hline \multicolumn{1}{c}{ Kelas } & KKM & $\begin{array}{c}\text { Nilai rata }- \\
\text { rata }\end{array}$ \\
\hline XI IPA BIO & 70 & 59,3 \\
XI IPA 1 & 70 & 55,2 \\
XI IPA 2 & 70 & 61,8 \\
\hline
\end{tabular}

Berdasarkan uraian di atas dapat disimpulkan bahwa penyebab rendahnya hasil belajar kimia karena materi termokimia merupakan pokok bahasan yang memerlukan tingkat pemahaman konsep yang cukup tinggi namun proses pembelajaran yang dilakukan masih kurang tepat serta dalam pembelajaran masih berpusat pada guru (Teaching Centered Learning), dan siswa tidak terlibat secara aktif dalam proses pembelajaran. Hal ini menyebabkan motivasi dan prestasi belajar siswa relatif rendah.
Sebagai tindak lanjut atas berbagai permasalahan maka perlu dilakukan penelitian tindakan (action research) yang berorientasi pada perbaikan kualitas pembelajaran melalui sebuah Penelitian Tindakan Kelas (PTK).

Bruner mengemukakan pendapatnya tentang motivasi atau keinginan untuk belajar dan cara-cara yang tersedia pada para guru untuk merangsang motivasi itu. Pengalamanpengalaman pendidikan yang merangsang motivasi adalah pengalaman dimana para siswa berpartisipasi aktif dalam proses pembelajaran yang dilakukan [2].

Untuk meningkatkan motivasi belajar siswa dalam memahami konsepkonsep yang tercakup dalam pembelajaran kimia dan meningkatkan prestasi belajar dapat digunakan metode Team Assisted Individualization (TAI) dilengkapi dengan menggunakan Lembar Kerja Siswa (LKS).

Model pembelajaran kooperatif tipe Team Assisted Individualization (TAI) menggabungkan pembelajaran kooperatif dengan pengajaran yang individual [3]. Model kooperatif tipe Team Assisted Individualization memberikan kesempatan pada siswa untuk saling mengajar (peer tutoring), saling mendukung, dan menggantikan bentuk persaingan (competition) dengan saling kerjasama (cooperation) [4]. Dalam pembelajaran dengan model kooperatif tipe Team Assisted Individualization (TAl), siswa memahami materi dan mengerjakan soal secara individu terlebih dahulu, sehingga pemahaman individu terasah. Selanjutnya siswa berdiskusi dengan kelompok untuk saling mengoreksi pekerjaan siswa satu sama lain dalam satu kelompok serta saling berbagi pemikiran dan saling membantu dalam memahami materi dengan cara pengajaran teman sebaya (peer teaching), kemudian siswa mengerjakan kuis secara individu, dilanjutkan guru memberikan penghargaan kelompok kepada kelompok dan individu berdasarkan perolehan nilai. Penerapan model kooperatif tipe Team Assisted Individualization (TAI) mendorong siswa terlibat langsung secara aktif dalam 
pembelajaran, sehingga siswa dapat memahami konsep termokimia.

Mengacu pada penelitian terdahulu penerapan model kooperatif mampu meningkatkan prestasi belajar siswa, salah satu model pembelajaran kooperatif yaitu tipe Team Assisted Individualization (TAI). Dalam penelitian tersebut, dengan penerapan Team Assisted Individualization (TAI) mampu meningkatkan aktivitas dan prestasi belajar siswa [5]. Pada penelitian lain, menyatakan bahwa pembelajaran aktif tipe Team Assisted Individualization (TAl) mampu meningkatkan kemampuan siswa dalam pemahaman konsep dan melibatkan siswa aktif dalam pembelajaran [6]. Penelitian lain menyatakan model pembelajaran Team Assisted Individualization (TAI) dapat meningkatkan sikap siswa terhadap matematika [7].

Langkah pembelajaran model kooperatif tipe Team Assisted Individualization (TAI) yaitu: (1) guru memberikan tugas/LKS beserta petunjuknya untuk dipelajari secara individu, (2) guru memberikan kuis kepada masing-masing siswa untuk mendapatkan skor awal, (3) guru mengelompokkan siswa secara heterogen yang terdiri dari 5-6 siswa serta menjelaskan pola kerja sama kelompok, (4) hasil belajar (tugas/ LKS) siswa didiskusikan dalam kelompok, (5) guru menjelaskan materi yang dipresentasikan, (6) guru memberikan evaluasi kepada siswa secara individu, (7) guru memberikan peringkat kelompok dan penghargaan kepada kelompok ber-dasarkan perolehan skor, (8) guru memberikan kesimpulan materi. Selain itu penggunaan LKS juga diterapkan untuk mempermudah siswa dalam memahami materi yang diberikan dan sebagai bahan ajar yang ringkas dan kaya tugas untuk berlatih siswa pada materi termokimia yang dianggap rumit [6].

Berdasarkan uraian tersebut, maka dilakukan penelitian mengenai Penerapan model pembelajaran Team Assisted Individualization (TAl) dengan berbantuan Lembar Kerja Siswa (LKS) untuk meningkatkan motivasi dan prestasi belajar siswa pada materi termokimia kelas XI IPA SMA Negeri 1 Slogohimo tahun ajaran 2015/2016.

\section{METODE PENELITIAN}

Penelitian ini merupakan penelitian tindakan kelas (Classroom Action Research) yang dilaksanakan dalam dua siklus dimana pada setiap siklus terdiri dari beberapa tahap yaitu persiapan, perencanaan, pelaksanaan, observasi, dan refleksi.

Subjek penelitian adalah siswa kelas XI IPA 1 semester ganji SMA N 1 Slogohimo Wonogiri tahun pelajaran $2015 / 2016$. Obyek penelitian ini adalah motivasi dan prestasi belajar siswa.

Data penelitian yang dikumpul-kan dalam penelitian ini meliputi data informasi tentang keadaan siswa secara aspek kualitatif dan kuantitatif. Aspek kualitatif meliputi data lapangan tentang hasil observasi, wawancara, kajian dokumen atau arsip yang menggambarkan proses belajar mengajar di kelas, kesulitan yang dialami guru ketika proses belajar mengajar serta model pembelajaran yang biasa digunakan. Aspek kuantitatif meliputi data penilaian prestasi belajar siswa pada materi termokimia yang meliputi aspek kognitif dan afektif baik siklus I maupun siklus II.

Teknik pengumpulan data dilakukan dengan observasi, wawancara dan angket. Analisis data dilakukan dalam tiga tahap yaitu reduksi data, penyajian data dan penarikan kesimpulan [8]. Teknik validitas data yang digunakan dalam penelitian ini adalah triangulasi. Instrumen diujicobakan terlebih dahulu yang dilaksanakan di kelas yang tidak di-gunakan penelitian dan divalidasi isi oleh dua panelis.

\section{HASIL DAN PEMBAHASAN}

Berdasarkan hasil wawancara dan observasi, terdapat permasalahanpermasalahan yang dapat disimpulkan bahwa di kelas XI IPA 1 mempunyai permasalahan yaitu pada prestasi dan motivasi belajar rendah. Oleh karena itu, perlu adanya upaya untuk mengatasi permasalah tersebut dengan menerapkan metode yang sesuai. 
Berdasarkan hasil observasi dan wawancara terhadap guru mata pelajaran kimia dapat disimpulkan bahwa siswa mengalami kesulitan dalam mempelajari materi termokimia. Motivasi belajar siswa tergolong rendah. Penelitian dilaksanakan dalam 2 siklus.

\section{Siklus I}

\section{a. Perencanaan}

Tahap ini meliputi penyusunan Rencana Pelaksanaan Pembelajaran (RPP) yang didasarkan pada silabus pelajaran kimia, penyusunan penilaian motivasi belajar siswa, penyusunan penilaian aspek kognitif, dan penyusunan penilaian aspek afektif. Siklus I terdiri dari 3 kali pertemuan untuk menyampaikan materi dan 1 kali untuk evaluasi.

\section{b. Pelaksanaan Tindakan}

Siklus I dilaksanakan pada tanggal 22 September-1 Oktober 2015. Pada tahap awal pembelajaran, guru mengawali materi dengan memberikan pertanyaan kepada siswa, pengajuan pertanyaan tersebut bertujuan untuk menggali pengetahuan awal siswa. Kemudian guru melanjutkan materi dengan memberikan informasi konsepkonsep yang terdapat dalam materi Termokimia. Guru sesekali memberikan umpan atau pertanyaan agar siswa mau bertanya maupun menjawab.

Tahap berikutnya adalah student creative. Pada tahap ini semua siswa dalam kelompok masing-masing mencari informasi tentang materi pokok Termokimia. Siswa membaca buku literatur dan LKS. Kemudian guru memberikan permasalahan terkait sub pokok materi yang diajarkan.

Guru kemudian meminta siswa untuk berdiskusi dalam kelompoknya masing-masing. Permasalahan yang didiskusikan siswa sudah ada dalam LKS yang diberikan guru dibantu oleh asisten (team study). Tahap berikutnya adalah whole class unit yang dimulai dengan siswa menyajikan hasil diskusi di depan kelas dan kelompok lain menanggapi.

Pada tahap akhir guru membimbing siswa untuk menyimpulkan materi yang sudah dipelajari. Selanjutnya guru memberikan evaluasi terhadap pembelajaran pada pertemuan pertama dengan memberikan soal post test (fact test). Pada tahap ini guru memberikan 4 butir soal uraian yang dikerjakan secara individu dalam waktu 10 menit. Pada akhir pembelajaran guru memberikan penghargaan kepada kelompok terbaik (team scores and team recognition) dan menyampaikan rencana pembelajaran pada pertemuan berikutnya .

Pada tahap ini siswa tampak belum terbiasa mengikuti proses pembelajaran, namun setelah dilakukan pengulangan siswa sangat antusias melakukannya dan suasana pembelajaran menjadi menyenangkan. Guru memberikan kesempatan pada kelompok lain untuk bertanya atau memberikan pendapat setelah salah satu kelompok mempresentasikan hasil diskusi. Pada tahap ini siswa diberi kebebasan untuk mengutarakan pendapat mereka.

\section{c. Pengamatan}

Pengamatan terhadap motivasi belajar siswa dilakukan selama proses pembelajaran berlangsung. Data yang diperoleh dalam penelitian ini adalah data motivasi belajar siswa, dan prestasi belajar siswa yang meliputi aspek kognitif dan afektif.

Aspek yang dinilai dari motivasi belajar siswa, antara lain: ketekunan dalam belajar, sikap pantang menyerah, minat, tingkat kebosanan, dan keberanian bertanya atau berpendapat. Data motivasi belajar siswa yang diperoleh meliputi observasi, angket, dan wawancara guru mata pelajaran kimia. Ringkasan hasil pengambilan data motivasi belajar siswa disajikan dalam Tabel 2.

Tabel 2. Hasil Motivasi Belajar Siswa Siklus I

\begin{tabular}{lc}
\hline \multicolumn{1}{c}{ Kriteria } & Persentase (\%) \\
\hline Sangat Tinggi & 11,54 \\
Tinggi & 57,69 \\
Rendah & 30,77 \\
\hline
\end{tabular}


Target keberhasilan motivasi belajar siswa adalah $75 \%$. Hasil penilaian motivasi menunjukkan bahwa kategori sangat tinggi sebanyak $11,54 \%$, siswa dengan kategori tinggi sebanyak $57,69 \%$, dan siswa dengan kategori rendah sebanyak $30,77 \%$.

Data prestasi belajar siswa aspek kognitif diambil pada akhir siklus I berupa tes objektif. Ringkasan hasil penilaian aspek kognitif disajikan dalam Tabel 3.

Tabel 3. Hasil Penilaian Aspek Kognitif Siklus I

\begin{tabular}{cc}
\hline Kategori & Persentase (\%) \\
\hline Tuntas & 46,15 \\
Tidak Tuntas & 53,85 \\
\hline
\end{tabular}

Target ketuntasan aspek kognitif adalah $75 \%$ siswa mencapai ketuntasan dengan KKM 75. Hasil dari siklus I menunjukkan masih diperlukan perbaikan terhadap pembelajaran yang dilaksanakan agar ketuntasan belajar siswa meningkat. Oleh karena itu, dilakukan serangkaian perencanaan untuk pelaksanaan siklus II.

Data prestasi belajar aspek afektif didapatkan berdasarkan observasi selama pembelajaran, angket penilaian aspek afektif, dan wawancara guru mata pelajaran kimia. Aspek yang dinilai pada prestasi belajar afektif siswa antara lain sikap, minat, konsep diri, nilai, dan moral. Ringkasan hasil penilaian aspek afektif disajikan dalam Tabel 4.

Tabel 4. Hasil Penilaian Aspek Afektif Siklus I

\begin{tabular}{cc}
\hline Kategori & Persentase (\%) \\
\hline Sangat Baik & 3,85 \\
Baik & 38,46 \\
Kurang Baik & 57,69 \\
\hline
\end{tabular}

\section{d. Refleksi}

Dari target keberhasilan pada siklus I dapat diketahui bahwa persentase ketiga aspek yang dinilai yaitu aspek kognitif, aspek afektif, dan motivasi belajar siswa belum mencapai target. Sehingga perlu dilakukan perbaikan pada siklus II. Tindakan siklus II yang diharapkan nantinya dapat menuntaskan untuk kedua indikator kompetensi yang belum mencapai target ketuntasan. Selain mengupayakan untuk meningkatkan hasil belajar, juga diupayakan untuk mempertahankan pencapaian prestasi belajar yang telah tercapai dan diupayakan adanya peningkatan yang lebih tinggi dari target yang sudah dicapai di siklus I.

Dari analisis aspek kognitif, masih terdapat tiga indikator kompetensi yang belum dikuasai siswa yaitu menghitung perubahan entalpi dengan menggunakan perubahan entalpi pembentukan standar, menghitung perubahan entalpi dengan menggunakan hukum Hess, dan menghitung perubahan entalpi dengan menggunakan data energi ikatan. Belum tercapainya tiga indikator tersebut dikarenakan siswa menyatakan bahwa materi perhitungan perubahan entalpi relatif cukup sulit dalam hal perhitungan yang lebih rumit.

Pelaksanaan siklus II berbeda dengan siklus I. Perbedaan dari siklus I dan II adalah pada siklus I dalam satu kelompok terdapat 1 asisten yang membantu dalam pembelajaran, sedangkan pada siklus II asisten dibantu dengan siswa yang sudah tuntas. Sehingga pembagian kelompok pada siklus II dimodifikasi agar dalam satu kelompok terdapat satu asisten dan minimal satu siswa yang sudah tuntas.

\section{Siklus II}

\section{a. Perencanaan}

Peneliti bersama guru mendiskusikan rancangan pelaksanaan tindakan yang dilakukan dalam penelitian siklus II. Pada proses pembelajaran siklus II, penyampaian materi difokuskan pada indikator kompetensi yang belum mencapai target $75 \%$.

Siklus II pada penelitian ini terdiri dari 1 kali pertemuan untuk pendalaman materi dan 1 kali untuk evaluasi. Materi yang disampaikan pada siklus II merupakan materi pada indikator kompetensi yang belum tuntas pada 
evaluasi siklus I. Dari analisis aspek kognitif, masih terdapat tiga indikator kompetensi yang belum dikuasai siswa yaitu menghitung perubahan entalpi dengan menggunakan perubahan entalpi pembentukan standar, menghitung perubahan entalpi dengan menggunakan hukum Hess, dan menghitung perubahan entalpi dengan menggunakan data energi ikatan.

\section{b. Pelaksanaan Tindakan}

Pembelajaran dimulai dengan guru menjelaskan secara singkat materi yang belum tuntas pada evaluasi pada siklus $\mathrm{I}$. kemudian dilanjutkan dengan siswa berdiskusi bersama kelompoknya dengan bantuan asisten.

Pada pelaksanaan siklus II, kelompok diskusi berbeda dari siklus I. Kelompok baru ini dibuat secara heterogen dengan berpedoman pada hasil di siklus I, dimana siswa dibagi menjadi 5 kelompok dan setiap kelompok terdiri dari 5-6 siswa. Pada kelompok baru ini peran asisten dibantu oleh siswa yang sudah tuntas pada evaluasi siklus I. Hal ini dimaksudkan agar siswa lebih bisa menyesuaikan diri dengan semua temannya, selain itu dengan kelompok baru tersebut diharapkan siswa lebih mudah berkoordinasi untuk memecahkan permasalahan yang diberikan dan pembagian tugas antar anggota kelompok lebih jelas.

\section{c. Pengamatan}

Penilaian terhadap aspek kognitif siswa dilaksanakan pada akhir siklus berupa soal pilihan ganda yang terdiri dari 20 butir soal pada indikator yang belum tercapai di siklus I.

Ringkasan hasil pengambilan data prestasi belajar aspek kognitif dan afektif siswa pada siklus II disajikan dalam Tabel 5 dan Tabel 6.

Tabel 5. Hasil Penilaian Aspek Kognitif Siklus II

\begin{tabular}{cc}
\hline Kategori & Persentase (\%) \\
\hline Tuntas & 100 \\
Tidak Tuntas & 0 \\
\hline
\end{tabular}

Tabel 6. Hasil Penilaian Aspek Afektif Siklus II

\begin{tabular}{cc}
\hline Kategori & Persentase (\%) \\
\hline Sangat Baik & 38,46 \\
Baik & 61,54 \\
\hline
\end{tabular}

Ringkasan hasil pengambilan data aspek motivasi belajar siswa pada siklus II disajikan dalam Tabel 7.

Tabel 7. Hasil Motivasi Belajar Siswa Siklus II

\begin{tabular}{cc}
\hline Kriteria & Persentase (\%) \\
\hline Sangat Tinggi & 46 \\
Tinggi & 54 \\
\hline
\end{tabular}

Berdasarkan analisis hasil penilaian siklus II, dapat disimpulkan bahwa penerapan model pembelajaran Team Assisted Individualization (TAI) pada materi Termokimia telah berhasil ditunjukkan dengan penilaian aspek kognitif, afektif dan motivasi belajar siswa yang telah memenuhi target ketuntasan yang ditentukan sehingga pembelajaran dapat diakhiri pada siklus II.

\section{Perbandingan Antar Siklus}

Secara umum, pembelajaran pada siklus II mempunyai hasil yang lebih baik dibandingkan dengan siklus I. Perbandingan hasil tindakan antarsiklus ditunjukkan pada Gambar 1.

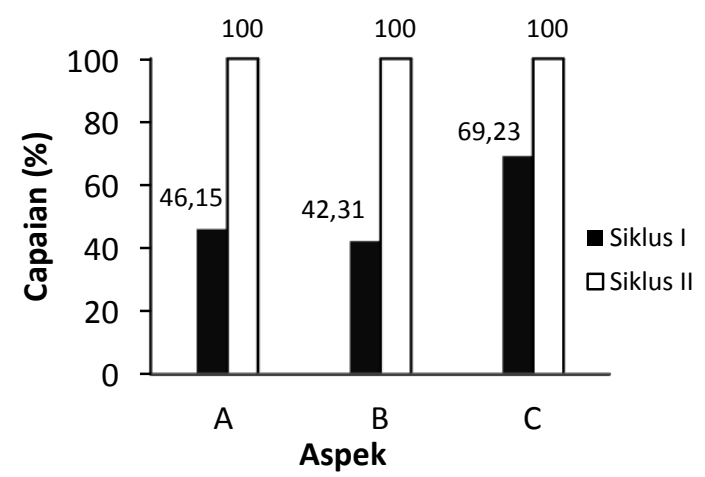

Gambar 1. Perbandingan ketercapaian antar siklus

Keterangan:

$$
\begin{aligned}
& A=\text { Kognitif } \\
& B=\text { Afektif } \\
& C=\text { Motivasi Belajar Siswa }
\end{aligned}
$$


Berdasarkan hasil yang telah dipaparkan, secara keseluruhan dapat dilihat bahwa penerapan model pembelajaran Team Assisted Individualization (TAI) pada materi Termokimia kelas XI IPA 1 SMA Negeri 1 Slogohimo tahun pelajarab 2015/2016 mampu meningkatkan prestasi belajar berupa aspek kognitif dan afektif, serta meningkatkan motivasi belajar siswa.

\section{KESIMPULAN}

Berdasarkan penelitian yang pernah dilakukan, dapat disimpulkan bahwa penerapan model pembelajaran Team Assisted Individualization (TAI) berbantuan Lembar Kerja Siswa (LKS) dapat meningkatkan motivasi dan prestasi belajar siswa kelas XI IPA 1 SMA Negeri 1 Slogohimo tahun pelajaran 2015/2016 pada materi Termokimia.

\section{UCAPAN TERIMA KASIH}

Penelitian ini dapat selesai dengan baik karena bantuan dari berbagai pihak. Oleh karena itu, penulis mengucapkan terima kasih kepada Bapak Singgih Santoso, S.Pd., M.Pd. selaku Kepala SMA Negeri 1 Slogohimo yang telah mengijinkan peneliti melakukan penelitian di SMA Negeri 1 Slogohimo dan kepada lbu Dra. Dwi Mulat Sudasmaningsih, M.Pd. selaku guru kimia SMA Negeri 1 Slogohimo yang telah berkenan mengijinkan peneliti melaksanakan penelitian di kelas yang belau ampu dan berkolaborasi dengan peneliti demi terselesaikannya penelitian.

\section{DAFTAR RUJUKAN}

[1] Sanjaya, W. (2008). Kurikulum dan Pembelajaran: Teori dan Praktek Pengembangan KTSP. Jakarta: Kencana.

[2] Dahar, R. W. (2011). Teori-Teori Belajar dan Pembelajaran. Jakarta: Erlangga.
[3] Slavin, R.E. (2009). Cooperative Learning Teori, Riset, dan Praktik. Terj. Nurulita. Bandung: Nusa Media.

[4] Shoimin, A. (2014). 68 Model Pembelajaran Inovatif dalam Kurikulum 2013. Yogyakarta: ArRuzz Media

[5] Rejeki, G. S., \& Dwi, R. (2013). Jurnal Pendidikan Kimia, 2(3), 175181.

[6] Rahmatikasari, U. (2013). Penerapan Tipe Team Assisted Individualization (TAI) dalam Peningkatan Pembelajaran Matematika tentang Bilangan Pecahan Siswa Kelas V SD. Skripsi Dipublikasikan, Universitas Sebelas Maret, Surakarta.

[7] Awofala, A. O. A., Arigbabu, A. A., \& Awofala, A. A. (2013). Efectos of Framing and Team Assisted Individualised Instructional Strategies on Senior Secondary School Students' Attitudes Toward Mathematics. Acta Dicactica Napocensia, 6(1), 49-71.

[8] Sugiyono. (2010). Metode Penelitian Pendidikan. Bandung: Alfabeta 